\title{
Prevalence of common mental disorder and associated factors among pregnant women in South-East Ethiopia, 2017: a community based cross-sectional study
}

Ashenafi Mekonnen Woldetsadik', Abebaw Nigussie Ayele ${ }^{2}$, Adem Esmael Roba ${ }^{3}$, Genet Fikadu Haile ${ }^{4}$ and Khan Mubashir ${ }^{5^{*}}$

\begin{abstract}
Background: Mothers suffering from common mental disorder (CMD), such as anxiety and depression may not be able to function properly, which could adversely affect the mother-infant bond and even result in increased infant morbidity and mortality. The purpose of this study was to assess the prevalence of CMD and its determinants among pregnant women in Southeast Ethiopia.

Methods: Data was collected from 743 pregnant women via interview-administered, standardised questionnaires during Dec-Jan 2017. The WHO Self-Reported Questionnaire (SRQ) was used to screen CMD. Multivariate logistic regression was conducted and ORs and 95\% confidence intervals were calculated.

Results: The prevalence of CMD during pregnancy was 35.8\% (95\% Cl: 34-38\%) and the main determinants of CMD were: illiteracy, presence of health risk, financial instability, physical or emotional abuse, having sexual intercourse without her willingness, family history of psychiatric illness and history of chronic medical illness.
\end{abstract}

Conclusion: CMD prevalence during pregnancy was high, indicating a need to regularly screen pregnant women for CMD and its determinants as part of routine obstetric care.

Keywords: Common mental disorder, Pregnant mothers, Social support, South East Ethiopia, Forced sexual intercourse, Infant mortality

\section{Plain English summary}

Common mental disorder (CMD) like anxiety and depression are very common during pregnancy. Women with mental illness during pregnancy usually have poor physical health and may be associated with negative impact on child development. So this study was aimed to see the prevalence of CMD in pregnant women of southeast Ethiopia. We screened 743 pregnant women for CMD using the SRQ research tool developed by WHO. This study was community based and the women were asked questions during face to face interviews at their homes. The prevalence of CMD among the

\footnotetext{
* Correspondence: kmubashir216@gmail.com

${ }^{5}$ Department of Biochemistry, Madda Walabu University, Goba Referral

Hospital, School of Medicine, Bale Goba, Ethiopia

Full list of author information is available at the end of the article
}

pregnant women was found to be $35.8 \%$. Many factors like relationship problems, physical or emotional abuse, poor husband support, family history of psychiatric illness and history of chronic medical illness were found directly associated with CMD. Our study also revealed that the women who were forced for sexual intercourse, were illiterate, had pregnancy complications, or were having health risk and with financial instability had the likelihood of developing CMD.

\section{Background}

Globally, around 450 million people are living with mental illness [1]. In low and lower middle income countries the non-psychotic perinatal common mental disorder (CMD) is common primarily among poorer women with gender-based risks or a psychiatric history [2]. From

(c) The Author(s). 2019 Open Access This article is distributed under the terms of the Creative Commons Attribution 4.0 International License (http://creativecommons.org/licenses/by/4.0/), which permits unrestricted use, distribution, and 
2005 to 2009, out of 10, one pregnant women experienced at least one major depressive episode in one year [3]. In developing countries perinatal depression is common and one in three women had significant mental health disorder but is under-estimated public health concern in low and middle income countries making substantial contribution to maternal and infant morbidity and mortality [4]. In high-income countries perinatal mental illness is the leading cause of maternal morbidity and mortality and causes unfavorable impacts on short and long term physical and mental health of off springs [5, 6]. In low, middle and high income countries, the prevalence of CMD during pregnancy varies from 12 to $43 \%$ [7].

The main determinants of antenatal CMD are women's marital status, unplanned pregnancy, gestational age and bleeding [4], Furthermore, the presence of poor health status before conception like headache, diabetic mellitus, hypertension, absence of support from partner, history of intimate partner violence and being from low socioeconomic status also leads to antenatal CMD $[5,6]$.

A number of independent studies have identified the association between antenatal depression and adverse neurobehavioral outcomes including reduced social, emotional and cognitive functioning during childhood development [8]. Besides depression, anxiety disorders, eating disorders and psychosis are the antenatal mental disorders which are associated with pre-term delivery, low birth weight of newborn, increased infant mortality and postnatal psychosis causing subsequent emotional problems in the child and adolescent [9].

Ethiopia is one of the low income countries with high rates of mental health problems in pregnant women ranging from $9.2-33 \%$ in different areas of the Ethiopia [4]. Even though some studies have been carried out in Ethiopia to recognize the impact of this issue, but none of them has focused on South Eastern region [10-12]. So the current study was carried out in the Bale zone of South-East Ethiopia. This zone is considered to be the developed and representative area with much better antenatal facility available in this region. So this study was intended to assess the prevalence of CMD and its associated factors during pregnancy in South-East Ethiopia.

\section{Material and methods}

\section{Study design, population and sampling procedures}

A community based cross-sectional study was conducted in three administrative towns (Robe, Goba and Ginnir) of Bale zone South-East Ethiopia from December-January 2017. The three administrative towns encompass a total of seven Kebeles (Kebele is the smallest administrative unit in Ethiopia similar to that of ward); out of which Robe has three, Goba and Ginnir each has two Kebeles. Using a simple random sampling technique, one Kebele from Goba (East Goba), one from Ginnir (01 Kebele) and two from Robe town (Café Donsa and Baha Biftu) were selected. In the selected 3 towns the number of pregnant women registered by health extension workers was 2376 . Out of this, 1086 were found in Robe town, 840 and 450 in Goba and Ginnir towns respectively. The prevalence of CMD during pregnancy ranged from $9.2-33 \%$ in different areas of the Ethiopia [4, 10-12]. Hence, a single population proportion formula was used to obtain maximum sample size of 748 . Multistage sampling technique was used to select study subjects. The calculated sample size was proportionally allocated based on the estimated number of pregnant women in selected Kebeles. Therefore, 341 from Robe, 265 from Goba and 142 pregnant women from Ginnir town were selected for the study. Then, the study participant was selected using systematic random sampling technique at every $K^{\text {th }}$ interval; where $K^{\text {th }}$ is the ratio of estimated number of pregnant women in each Kebele to the proportionally allocated sample size for specific Kebele. Therefore, we accessed the pregnant women at every 3rd interval. From the first three women, the third one was selected by lottery method. With the help of antenatal registration book maintained by the health extension workers the selected participants were located and interviewed in their homes. All registered pregnant women at any trimester living in the study area for at least six months were included in the study except those taking antidepressants and who had known mental health problems.

\section{Data collection tools and procedures}

The data was collected by face to face interview using structured questionnaire addressing socio-demographic and obstetric characteristics of study participants which was developed after reviewing the literature. The List of threatening experience questionnaire (LTE-Q) [13] was adopted and modified in present context to assess the stressful life events. The Oslo-3 Social Support Scale (OSS) [14], the Abuse Assessment Screen (AAS) questions [15] and WHO's alcohol, smoking and substance involvement screening test (WHO-ASSIST V3.0) [16] were used to assess social support, presence of victimization and substance or alcohol abuse, respectively. To screen CMD during pregnancy, the standardized WHO's Self-Reporting Questionnaire (SRQ-20) was used and those who answered "Yes" to six or more of the twenty questions were categorized as CMD caseness (Yes, No). This criterion was validated by the study conducted in Butajira, Ethiopia [17]. Twelve trained data collectors and four supervisors were involved in the process. 


\section{Data quality control}

The questionnaires were translated from English into the local languages (Amharic and Afan Oromo) using language experts. To confirm that meaning was not altered in the translation process the translated questionnaires were tested for reliability and validity on $5 \%$ of the final sample size with pregnant women in Delomena, a town in Bale Zone that was not included in the study. The results obtained were found to be consistent with Amharic version, so there was no need to translate it back. Data collectors and supervisors received two days of training on proper instrument administration and study protocol. Throughout the data collection period, the supervisor monitored the data collectors and $10 \%$ of the collected daily data were checked by the field supervisors and principal investigator. Incomplete questionnaires were excluded from the study and counted as non-respondents.

\section{Data processing and analysis}

Double data entry was performed for all data and then Epi Info 7.1.2's validation program was used to check the completeness, accuracy and consistency of data and exported to statistical package for social sciences (SPSS) 21 for the analysis $[18,19]$. Descriptive statistics were calculated to obtain percentages, frequencies and means for all variables. Those variables with significance level ( $p$-value) $<0.05$ in bivariate analysis were entered into multivariate logistic regression model for further analysis in order to adjust the confounding factor on the dependent variables.

\section{Results}

The response rate of current study was $99.3 \%$.

\section{Socio-demographic factors}

The mean \pm SD age of participants was $27.3 \pm 5.2$ with the majority being $20-34$ years of age $(83.6 \%)$. As shown in Tables 1, 68.5\% were of the Oromo ethnic group and 43.7\% were Muslims. The majority of participants worked as housewives (61.1\%) and had either a primary or secondary school education (55.8\%). Most participants were married (96.4\%) and of these, over half of them had been married for more than 4 years (59.8\%) (Table 1).

\section{Obstetric care factors}

More than half of the participants (54.6\%) were in the second trimester of their pregnancy and had been pregnant 2-4 times before (58.8\%). In this sample, $21.4 \%$ had an unplanned pregnancy, $12.5 \%$ had history of abortion, and $4 \%$ had a prior history of a neonatal death. The participants who had at least one antenatal care (ANC)
Table 1 Socio-demographic characteristics of the participants in Bale Zone South East Ethiopia, $2017(n=743)$

\begin{tabular}{|c|c|c|}
\hline Variables & Frequency & $\begin{array}{l}\% \text { of the total } \\
\text { sample }\end{array}$ \\
\hline \multicolumn{3}{|l|}{ Age } \\
\hline$\leq 19$ years & 36 & 4.8 \\
\hline 20-34 years & 621 & 83.6 \\
\hline$\geq 35$ years & 86 & 11.6 \\
\hline \multicolumn{3}{|l|}{ Religious status } \\
\hline Muslim & 325 & 43.7 \\
\hline Orthodox & 254 & 34.2 \\
\hline Other & 164 & 22.1 \\
\hline \multicolumn{3}{|l|}{ Marital status } \\
\hline Married & 716 & 96.4 \\
\hline Others $^{\circledast}$ & 27 & 3.6 \\
\hline \multicolumn{3}{|l|}{ Ethnicity } \\
\hline Oromo & 509 & 68.5 \\
\hline Amhara & 170 & 22.9 \\
\hline Others ${ }^{\oplus \otimes}$ & 64 & 8.6 \\
\hline \multicolumn{3}{|l|}{ Educational status } \\
\hline Unable to read and write & 105 & 14.1 \\
\hline Able to read and write & 140 & 18.8 \\
\hline Primary school & 220 & 29.6 \\
\hline Secondary school & 196 & 26.4 \\
\hline Diploma and above & 82 & 11.0 \\
\hline \multicolumn{3}{|l|}{ Number of years married } \\
\hline$\leq 1$ year & 87 & 11.7 \\
\hline $2-4$ years & 212 & 28.5 \\
\hline$\geq 5$ years & 444 & 59.8 \\
\hline \multicolumn{3}{|l|}{ Occupation } \\
\hline Housewife & 454 & 61.1 \\
\hline Employed & 64 & 8.6 \\
\hline Merchant & 77 & 10.4 \\
\hline Private Employee & 71 & 9.6 \\
\hline Farmer & 39 & 5.2 \\
\hline Unemployed & 38 & 5.1 \\
\hline \multicolumn{3}{|l|}{ Husband's education } \\
\hline Unable to read and write & 74 & 10.0 \\
\hline Able to read and write & 123 & 16.6 \\
\hline Primary school & 163 & 21.9 \\
\hline Secondary school & 246 & 33.1 \\
\hline Diploma & 81 & 10.9 \\
\hline Degree and above & 56 & 7.5 \\
\hline \multicolumn{3}{|c|}{ Family member indebted in the last six months } \\
\hline Yes & 78 & 10.5 \\
\hline No & 665 & 89.5 \\
\hline
\end{tabular}

Hunger within the last six months 
Table 1 Socio-demographic characteristics of the participants in Bale Zone South East Ethiopia, 2017 ( $n=743)$ (Continued)

\begin{tabular}{lll}
\hline Variables & Frequency & $\begin{array}{l}\% \text { of the total } \\
\text { sample }\end{array}$ \\
\hline Yes & 52 & 7.0 \\
No & 691 & 93.0 \\
Family wealth in relation to others & & \\
Low & 235 & 31.6 \\
Moderate & 415 & 55.9 \\
High & 93 & 12.5
\end{tabular}

Note: other; protestant and catholic, Others ${ }^{\ominus}$; Single, divorced, widowed and separated, others ${ }^{\oplus \bullet}$; Tigray, Gurage, Wolayita and Seltie, unemployed ${ }^{\oplus \bullet \bullet}$, student and daily laborer

follow up for the current pregnancy accounted up to $90.8 \%$ (Table 2).

\section{Psychosocial factors}

Amongst the participants, $14.4 \%$ had financial instability, $10.9 \%$ had legal problems, $8.1 \%$ had relationship issues, $7.9 \%$ had health risks, and $5.5 \%$ had lost a loved one. Seventy-seven (10.4\%) reported that they had been emotionally or physically abused during their lifetime and $6.2 \%$ reported abuse during the current pregnancy. Thirty-four $(4.6 \%)$ participants reported being forced to have sexual intercourse within the last year and of these, the majority $(88.2 \%)$ reported that it was their husband who forced them for intercourse (Table 3).

\section{Substance abuse}

Most participants reported no substance abuse, $25.2 \%$ of the participants reported ever drinking alcoholic beverages and $10.4 \%$ reported ever chewing khat. Of those who drink alcohol, $46.5 \%$ reported having alcohol on a monthly basis (Table 4).

\section{Clinical factors}

Participants were asked about various clinical conditions and forty-five $(6.1 \%)$ reported to have a history of chronic medical illness and $10(1.3 \%)$ had a history of psychiatric illness. Additionally, 58 (7.8\%) had a family history of psychiatric illness.

\section{Common mental disorders}

The SRQ-20 was used to assess the prevalence of common mental disorder amongst the participants. The mean score was 3.75 and 266 (35.8\%; 95\% CI: 34-38\%) participants had total scores of 6 or higher suggesting that they were experiencing mental health problems during their pregnancy. The symptoms experienced most frequently were: tiring easily $(n=328,44.2 \%)$, often having headaches $(n=238,32.0 \%)$, having a poor appetite $(n=214,28.8 \%)$ and experiencing uncomfortable feelings in the stomach $(n=168,22.6 \%)$.
Table 2 Obstetric characteristics of participants in Bale Zone South East Ethiopia, 2017 ( $n=743)$

\begin{tabular}{|c|c|c|}
\hline Variables & Frequency & $\begin{array}{l}\% \text { of the total } \\
\text { sample }\end{array}$ \\
\hline \multicolumn{3}{|l|}{ Pregnancy planned } \\
\hline Yes & 584 & 78.6 \\
\hline No & 159 & 21.4 \\
\hline \multicolumn{3}{|c|}{ Total number of pregnancies } \\
\hline & 184 & 24.8 \\
\hline $2-4$ & 437 & 58.8 \\
\hline$\geq 5$ & 122 & 16.4 \\
\hline \multicolumn{3}{|c|}{ Gestational age of pregnancy } \\
\hline First trimester & 55 & 7.4 \\
\hline Second trimester & 406 & 54.6 \\
\hline Third trimester & 282 & 38.0 \\
\hline \multicolumn{3}{|c|}{ Number of alive children } \\
\hline 0 & 197 & 26.5 \\
\hline $1-2$ & 334 & 45.0 \\
\hline$\geq 3$ & 212 & 28.5 \\
\hline \multicolumn{3}{|c|}{ Past history of still birth } \\
\hline Yes & 51 & 6.9 \\
\hline No & 692 & 93.1 \\
\hline \multicolumn{3}{|l|}{ History of abortion } \\
\hline Yes & 93 & 12.5 \\
\hline No & 650 & 87.5 \\
\hline \multicolumn{3}{|c|}{ Previous history of neonatal death } \\
\hline Yes & 30 & 4.0 \\
\hline No & 713 & 96.0 \\
\hline \multicolumn{3}{|c|}{ History of past pregnancy complication } \\
\hline Yes & 123 & 16.6 \\
\hline No & 620 & 83.4 \\
\hline \multicolumn{3}{|c|}{ Complication with current pregnancy } \\
\hline Yes & 100 & 13.5 \\
\hline No & 643 & 86.5 \\
\hline \multicolumn{3}{|c|}{ ANC follow-up for current pregnancy } \\
\hline Yes & 675 & 90.8 \\
\hline No & 68 & 9.2 \\
\hline
\end{tabular}

Factors associated with common mental disorders during pregnancy

Adjusting for inability to read and write $(\mathrm{AOR}=2.06$; 95\% CI: $1.05-4.04)$, health risks $(\mathrm{AOR}=2.94 ; 95 \% \mathrm{CI}$ : 1.53-5.66), financial instability $(\mathrm{AOR}=1.72$; $95 \% \mathrm{CI}$ : 1.06-2.82), physical or emotional abuse (AOR $=2.40$; 95\% CI: 1.36-4.24), forced sexual intercourse in last one year $(\mathrm{AOR}=3.85 ; 95 \% \mathrm{CI}: 1.67-8.88)$, family history of psychiatric illness $(\mathrm{AOR}=3.14 ; 95 \% \mathrm{CI}: 1.66-5.94)$ and history of chronic medical illness $(\mathrm{AOR}=3.26$; $95 \% \mathrm{CI}$ : 
Table 3 Psychosocial characteristics of participants in Bale Zone South East Ethiopia, 2017 ( $n=743$ )

\begin{tabular}{llll}
\hline Variables & Frequency & \% of the total sample & Relative \% \\
\hline Health risk & & \\
Yes & 59 & 7.9 \\
No & 684 & 92.1
\end{tabular}

Loss of loved one

$\begin{array}{lll}\text { Yes } & 41 & 5.5 \\ \text { No } & 702 & 94.5\end{array}$

Financial stress

$\begin{array}{lll}\text { Yes } & 107 & 14.4 \\ \text { No } & 636 & 85.6\end{array}$

Legal problem

$\begin{array}{lll}\text { Yes } & 81 & 10.9\end{array}$

No $\quad 662 \quad 89.1$

Relationship problem

$\begin{array}{lll}\text { Yes } & 60 & 8.1 \\ \text { No } & 683 & 91.9\end{array}$

History of emotional or physical abuse

$\begin{array}{lll}\text { Yes } & 77 & 10.4 \\ \text { No } & 666 & 89.6\end{array}$

Have you been abused during this pregnancy

$\begin{array}{lll}\text { Yes } & 46 & 6.2 \\ \text { No } & 697 & 93.8\end{array}$

If you are abused during the current pregnancy, by whom

$\begin{array}{llr}\text { Partner } & 43 & 93.5 \\ \text { Others } & 3 & 6.5\end{array}$

Forced sexual activities in last one year

$\begin{array}{lll}\text { Yes } & 34 & 4.6 \\ \text { No } & 709 & 95.4\end{array}$

Perpetrator of forced sex

$\begin{array}{ll}\text { Partner } & 30 \\ \text { Others }^{\oplus} & 4\end{array}$

Others $^{\oplus}$

11.8

On how many people do you rely in home

$\begin{array}{lll}>5 & 306 & 41.2 \\ 3-5 & 226 & 30.4 \\ 1-3 & 179 & 24.1 \\ \text { None } & 32 & 4.3\end{array}$

Number of people showing interest in what you do

$\begin{array}{lll}\text { A lot } & 241 & 32.4 \\ \text { Some } & 177 & 23.8 \\ \text { Uncertain } & 190 & 25.6 \\ \text { Little } & 69 & 9.3 \\ \text { None } & 66 & 8.9\end{array}$

Participant's neighbour

Very difficult 52
Table 3 Psychosocial characteristics of participants in Bale Zone South East Ethiopia, 2017 ( $n=743$ ) (Continued)

\begin{tabular}{llll}
\hline Variables & Frequency & $\%$ of the total sample & Relative \% \\
\hline Difficult & 117 & 15.7 \\
Possible & 242 & 32.6 \\
Easy & 212 & 28.5 \\
Very easy & 120 & 16.2 \\
Husband's support for the continuation of pregnancy \\
Stronger & 413 & 55.5 \\
Moderate & 256 & 34.5 \\
Poor & 74 & 10.0 \\
Family support for continuation of pregnancy \\
Yes & 553 & 74.4 \\
No & 190 & 25.6
\end{tabular}

Note: Other- family member, stranger Others ${ }^{\oplus}$ : family member, stranger

1.64-6.48) showed statistically significant association $(p<0.05)$ with CMD (Table 5).

\section{Discussion}

The overall prevalence of CMD during pregnancy from our study finding was $35.8 \%$ (95\% CI: $34-38 \%$ ), which is higher than the studies conducted in Maringa Parana (12.9\%) [20], Brazil (20.2\%) [21], Pakistan (18\%) [22], Peru (30\%), Vietnam (21\%), India (30\%) [23], Nigeria (7\%) [24] and Kilimanjaro (28.8\%) [25], and slightly lower than reported in Tanzania (39.5\%) [26] and in the

Table 4 Substance abuse by the participants in Bale Zone South East Ethiopia, 2017 ( $n=743)$

Variable $\quad$ Frequency \% of the total sample Relative \%
Ever drank alcohol beverage

$\begin{array}{lll}\text { Yes } & 187 & 25.2 \\ \text { No } & 556 & 74.8\end{array}$

How often drank alcohol beverage

$\begin{array}{lll}\text { Once or twice } & 55 & 29.4 \\ \text { Monthly } & 87 & 46.5 \\ \text { Weekly } & 31 & 16.6 \\ \text { Daily } & 10 & 5.3 \\ \text { Almost daily } & 4 & 2.1\end{array}$

Ever used substance like khat

$\begin{array}{lll}\text { Yes } & 77 & 10.4 \\ \text { No } & 666 & 89.6\end{array}$

How often have you used substance

$\begin{array}{lll}\text { Once or twice } & 24 & 31.2 \\ \text { Monthly } & 26 & 33.8 \\ \text { Weekly } & 14 & 18.2 \\ \text { Daily } & 10 & 13.0 \\ \text { Almost daily } & 3 & 3.8\end{array}$


Table 5 Factors associated with common mental disorder during pregnancy in participants in Bale Zone South East Ethiopia, 2017

\begin{tabular}{|c|c|c|c|c|}
\hline \multirow[t]{2}{*}{ Variables } & \multicolumn{2}{|c|}{ CMD } & \multirow{2}{*}{$\begin{array}{l}\text { Crude OR with } \\
95 \% \mathrm{Cl}\end{array}$} & \multirow{2}{*}{$\begin{array}{l}\text { Adjusted OR with } \\
95 \% \mathrm{Cl}\end{array}$} \\
\hline & Yes & No & & \\
\hline \multicolumn{5}{|l|}{ Educational status } \\
\hline $\begin{array}{l}\text { Unable to read } \\
\text { and write }\end{array}$ & 57 & 48 & $2.87(1.56-5.29)$ & $2.06(1.05-4.04)^{*}$ \\
\hline Read and write & 49 & 91 & $1.30(0.68-2.47)$ & $1.30(0.68-2.47)$ \\
\hline Primary school & 75 & 145 & $1.25(0.72-2.17)$ & $1.06(0.58-1.93)$ \\
\hline Secondary school & 61 & 135 & $1.09(0.62-1.92)$ & $0.92(0.50-1.69)$ \\
\hline Diploma and above & 24 & 58 & 1.00 & 1.00 \\
\hline \multicolumn{5}{|l|}{ History of abortion } \\
\hline Yes & 47 & 46 & $2.01(1.30-3.12)$ & $1.34(0.80-2.34)$ \\
\hline No & 219 & 431 & 1.00 & 1.00 \\
\hline \multicolumn{5}{|l|}{$\begin{array}{l}\text { History of pregnancy } \\
\text { complication in past }\end{array}$} \\
\hline Yes & 65 & 58 & $2.34(1.58-3.46)$ & $1.56(0.99-2.34)$ \\
\hline No & 201 & 419 & 1.00 & 1.00 \\
\hline \multicolumn{5}{|l|}{ Health risk } \\
\hline Yes & 222 & 457 & $4.65(2.61-8.27)$ & $2.94(1.53-5.66)^{* *}$ \\
\hline No & 41 & 18 & 1.00 & 1.00 \\
\hline \multicolumn{5}{|l|}{ Loss of loved one } \\
\hline Yes & 23 & 18 & $2.41(1.28-4.56)$ & $1.93(0.94-3.88)$ \\
\hline No & 243 & 459 & 1.00 & 1.00 \\
\hline \multicolumn{5}{|c|}{ Financial stress / instability } \\
\hline Yes & 65 & 42 & $3.35(2.20-5.11)$ & $1.72(1.06-2.82)^{*}$ \\
\hline No & 201 & 435 & 1.00 & 1.00 \\
\hline \multicolumn{5}{|l|}{ Relationship problem } \\
\hline Yes & 36 & 24 & $2.36(1.48-3.76)$ & $1.97(0.98-3.66)$ \\
\hline No & 230 & 453 & 1.00 & 1.00 \\
\hline \multicolumn{5}{|l|}{$\begin{array}{l}\text { Ever physically or } \\
\text { emotionally abused }\end{array}$} \\
\hline Yes & 51 & 26 & $4.12(2.50-6.78)$ & $2.40(1.36-4.24)^{* *}$ \\
\hline No & 215 & 451 & 1.00 & 1.00 \\
\hline
\end{tabular}

Forced sexual activities

in last one year

$\begin{array}{lllll}\text { Yes } & 24 & 10 & 4.63(2.18-9.84) & \mathbf{3 . 8 5}(\mathbf{1 . 6 7 - 8 . 8 8})^{* * *} \\ \text { No } & 242 & 467 & 1.00 & 1.00 \\ \text { Husbands support } & & & & \\ \text { Stronger } & 125 & 288 & 1.00 & 1.00 \\ \text { Moderate } & 92 & 164 & 1.29(0.93-1.80) & 0.93(0.64-1.35) \\ \text { Poor } & 49 & 25 & 4.52(2.67-7.64) & 1.07(0.58-3.89)\end{array}$

Practical family support

$\begin{array}{lllll}\text { Yes } & 172 & 381 & 1.00 & 1.00 \\ \text { No } & 94 & 96 & 2.17(1.55-3.04) & 1.47(0.98-2.21)\end{array}$

Table 5 Factors associated with common mental disorder during pregnancy in participants in Bale Zone South East Ethiopia, 2017 (Continued)

\begin{tabular}{|c|c|c|c|c|}
\hline \multirow[t]{2}{*}{ Variables } & \multicolumn{2}{|c|}{ CMD } & \multirow{2}{*}{$\begin{array}{l}\text { Crude OR with } \\
95 \% \mathrm{Cl}\end{array}$} & \multirow{2}{*}{$\begin{array}{l}\text { Adjusted OR with } \\
95 \% \mathrm{Cl}\end{array}$} \\
\hline & Yes & No & & \\
\hline \multicolumn{5}{|c|}{$\begin{array}{l}\text { Family history of } \\
\text { psychiatric illness }\end{array}$} \\
\hline Yes & 38 & 20 & $3.81(2.17-6.70)$ & $3.14(1.66-5.94)^{* *}$ \\
\hline No & 228 & 457 & 1.00 & 1.00 \\
\hline \multicolumn{5}{|c|}{$\begin{array}{l}\text { History of chronic } \\
\text { medical illness }\end{array}$} \\
\hline Yes & 28 & 17 & $3.18(1.71-5.93)$ & $3.26(1.64-6.48)^{* * *}$ \\
\hline No & 238 & 460 & 1.00 & 1.00 \\
\hline
\end{tabular}

Note: ${ }^{*} p$ value is significant at $p<0.05 * * p$ value is significant at $p<0.01$ $1.00=$ Reference for category

two Cape Town's peri-urban settlements (39\%) [27]. These differences in CMD prevalence might be attributed to differences in measurement tools used, level of knowledge and understanding of the participants, sample size and socio-cultural and economic variations. Similarly, within Ethiopia, there were also variations in CMD prevalence rates, all of which were lower than the current study; for example: Butajira (33\%) [10], Maichew (31.1\%) [11], Gondar University Hospital (23\%) [28], Debre Tabor town (11.8\%) [29] and Addis Ababa health facility $(24.94 \%)$ [30]. These variations may be due to differences in sample size, the time of study, the age, location, and educational status of participants and/or the tools used to diagnose CMD.

In the present study the women who were not able to read and write were 2.08 times more likely to have CMD than the literate women. Our findings were in agreement with a population-based cohort study in Southern Brazil where lower educational levels were significantly associated with antenatal depressive manifestations [31]. However a study conducted in rural Bangladesh, India and Pakistan reported that being literate [32] and spending more than 10 years in formal education were predisposing factors for CMD during pregnancy [33]. In addition to socio-economic and cultural differences this discrepancy may be due to the personal circumstances like the relationship quality with the intimate partner, empowerment at home and society and the workload in the populations studied.

Furthermore, in our study, women having a history of previous pregnancy-related complications had 1.59 times chance of development of CMD during pregnancy. While in two different studies conducted in Sao Paulo [34] and Debre Tabor Town [29], women with current pregnancy-related complications were at risk of developing CMD. This is obvious, since during pregnancy a 
women feels depressive state of mind and any kind of complication during this period may make it worse.

The socio-economic factors like financial instability and history of physical and/or emotional abuse showed the likelihood of CMD 1.88 and 2.47 times respectively. Our results were consistent with previous researches carried out in Ethiopia and other countries where financial instability was found to predict the development of CMD during pregnancy [11, 33, 35, 36] as did a history of physical and/or emotional abuse [24, 27, 32, 33, 37-39]. and forced sexual activities over the past year $[32,33]$. In addition to the basic needs of life, moral, social and financial support is important for the wellbeing of a person and lack of any of them may lead to mental instability. Similar to our current findings, the absence of husband's support during pregnancy in two peri-urban settlements in Cape Town [27] were the main predictors of CMD. Also a family history of psychiatric illness was significantly associated with CMD during pregnancy in the present study.

Lastly, in this study, pregnant women with a history of chronic medical illness were vulnerable for CMD, which are similar with the findings of a study conducted in Brazil, Maringa and Parana [20]. Women with chronic illnesses are more worried about their sickness and also remain detached from the social life, hence causing a disturbed mental state. A major limitation of current study is the use of a standardized screening tool to measure CMDs but not locally validated. Further it is a cross-sectional study, hence a temporal relationship could not be determined; only an association between the variables, and not causation, could be inferred. In our study we addressed that there is a strong knowledge gap in the pregnant women about CMD. Further our study is a community based study it can be generalized to the population at large.

\section{Conclusion}

The prevalence of self-reported CMD during pregnancy in Bale Zone south east Ethiopia is high. Being unable to read and write, a history of previous pregnancyrelated complications, financial instability, a history of physical or emotional abuse, being forced to engage in sexual intercourse activities over the past one year, poor husband support, a family history of psychiatric illness and a history of chronic medical illness are the main predictors for CMD during pregnancy. The Bale Zone health office in collaboration with key stakeholders should organize the seminars, conferences and create the awareness programs in communities regarding CMD. Further the women education should be encouraged and for this they should be morally and socially supported.

\section{Abbreviations}

AAS: Abuse Assessment screen; ANC: Antenatal Care.; CMD: Common Mental Disorder; LTE-Q: List of Threatening experience questionnaire; OR: Odds Ratio; OSS: Oslo 3 social support scale; SPSS: Statistical package for Social Sciences; SRQ: Self Reported Questionnaire; WHO: World Health Organization

\section{Acknowledgements}

We would like to thank all the pregnant women who participated in this study and the Bale Zone administrative office, data collectors and supervisors for their support and time. We would also like to express our gratitude to the Madda Walabu University, Research Community Engagement and Technology Transfer Office for their unreserved support.

\section{Authors' contributions}

AMW, ANA, GFH and KM designed the study and were involved in drafting and correcting the manuscript. AER and AMW carried out the data collection and together with GFH \& KM did the statistical analysis. All the authors read the manuscript, critically revised it for important intellectual content and approved the final version of the manuscript.

\section{Funding}

This research was funded by Madda Walabu University. The funder has no role in design, analysis, data interpretation and publication of the finding.

\section{Availability of data and materials}

All the available data and material used in this study is presented in the main paper.

\section{Ethics approval and consent to participate}

Ethical clearance was obtained from the Ethical Review Board of the Research, Community Engagement and Technology Transfer Office of Madda Walabu University. Then, permission letter was obtained from the Bale Zone Administrative Office to conduct this study. Data was collected after obtaining written consent from the study participant. For each positive case the participants were counseled on spot and guided for taking treatment from the respective health offices.

\section{Consent for publication}

Not applicable in this section.

\section{Competing interests}

The authors declare that they have no competing interests.

\section{Author details}

'Department of Midwifery, Madda Walabu University, Goba Referral Hospital, School of Health Science, Bale Goba, Ethiopia. ${ }^{2}$ Department of Physiology, Madda Walabu University, Goba Referral Hospital, School of Medicine, Bale Goba, Ethiopia. ${ }^{3}$ Department of Nursing, Madda Walabu University, Goba Referral Hospital, School of Health Science, Bale Goba, Ethiopia. ${ }^{4}$ Department of Midwifery, Madda Walabu University, Goba Referral Hospital, School of Health Science, Bale Goba, Ethiopia. ${ }^{5}$ Department of Biochemistry, Madda Walabu University, Goba Referral Hospital, School of Medicine, Bale Goba, Ethiopia.

Received: 19 December 2018 Accepted: 5 November 2019 Published online: 28 November 2019

\section{References}

1. WHO. The World Health Report 2001: Mental health: new understanding: New Hope World Health Organization; 2001.

2. Fisher J, de Mello MC, Patel V, Rahman A, Tran T, Holton S, Holmes W. Prevalence and determinants of common perinatal mental disorders in women in low and lower-middle-income countries: a systematic review. Bull World Health Organ. 2012.

3. Jean YK, Sherry LF, Cheryl LR. Depression and treatment among US pregnant and non-pregnant women of reproductive age, 2005-2009. J Women's Heal. 2012;21(8):830-6.

4. World Health Organisation. Maternal mental health and child health and development in low and middle income countries: World Health; 2008.

5. Ban L, Gibson JE, West J. Association between perinatal depression in mothers and the risk of childhood infections in offspring: a population- 
based cohort study. BMC Public Health. 2010. https://doi.org/10.1136/adc. 2010.183327.

6. Servili C, Medhin G, Hanlon C, Tomlinson M, Worku B, Bahferetibeb Y, Dewey M, Alem A, Prince M. Maternal common mental disorders and infant development in Ethiopia: the P-MaMiE birth cohort. BMC Public Health. 2010. https://doi.org/10.1186/1471-2458-10-693.

7. Stewart RC, Umar E, Tomenson B. A cross-sectional study of antenatal depression and associated factors in Malawi. Arch Womens Ment Health. 2014;17(2):145-54.

8. Wadhwa PD. Psychoneuroendocrine processes in human pregnancy influence fetal development and health. Psychoneuroendocrinology. 2005 Sep;30(8):724-43.

9. Vesga-Lopez O, Blanco C, Keyes K, Olfson M, Grant BF, Hasin DS. Psychiatric disorders in pregnant and postpartum women in the United States. Arch Gen Psychiatry. 2008;65(7):805-15.

10. Medhin G, Hanlon C, Dewey M, Alem A, Tesfaye F, Lakew Z, et al. The effect of maternal common mental disorders on infant undernutrition in Butajira, Ethiopia : The P-MaMiE study. BMC Psychiatry. 2010;10(32).

11. Tilahun B, Mossie TB, Sibhatu AK, Dargie A, Ayele AD. Prevalence of Antenatal Depressive Symptoms and Associated Factors among Pregnant Women in Maichew, North Ethiopia : An Institution Based Study. Ethiop J Heal Sci. 2017;27(1):59-66.

12. Hanlon C, Medhin G, Alem A, Araya M, Abdulahi A, Hughes M, et al. Detecting perinatal common mental disorders in Ethiopia: validation of the self-reporting questionnaire and Edinburgh postnatal depression scale. J Affect Disord. 2008;108(3):251-62.

13. Brugha T, Bebbington P, Tennant $C$, Hurry J. The list of threatening experiences: a subset of 12 life event categories with considerable longterm contextual threat. Psychol Med. 1985;15(1):189-94.

14. Dalgard OS, Dowrick C, Lehtinen V, Vazquez-Barquero JL, Casey P, Wilkinson G, Ayuso-Mateos JL, Page H, Dunn G. Negative life events, social support and gender difference in depression: a multinational community survey with data from the ODIN study. Soc Psychiatry Psychiatr Epidemiol. 2006;41(6):444-51.

15. Canterino JC, VanHorn LG, Harrigan JT, Ananth CV, Vintzileos AM. Domestic abuse in pregnancy: a comparison of a self-completed domestic abuse questionnaire with a directed interview. Am J Obstet Gynecol. 1999;181(5): 1049-51.

16. Henry-Edwards S, Humeniuk R, Ali R, Poznyak V, Monteiro M, Poznyak BV. ASSIST guidelines for use in primary care. Geneva, World Health Organization: In; 2003.

17. Beusenberg M, Orley J. A user's guide to the self reporting questionnaire (SRQ). Geneva: World Health Organization; 1994. p. 84

18. Christiansen TB, Lauritsen JM. (Ed.) EpiData - comprehensive data management and basic statistical analysis system. Odense Denmark, EpiData association, 2010. http://www.epidata.dk;

19. IBM Corp. Released 2012. IBM SPSS statistics for windows, version 21.0. Armonk, NY: IBM Corp].

20. Kassada DS, Waidman MAP, Marcon Al. Prevalence of mental disorders and associated factors in pregnant women. Acta Paul Enferm. 2015;28(6):495-502.

21. Faisal-cury A, Menezes PR. Common mental disorders during pregnancy: prevalence and associated factors among low- income women in São Paulo. Brazil Arch Womens Ment Heal. 2009;12:335-43.

22. Ali NS, Azam IS. Frequency and associated factors for anxiety and depression in pregnant women: a hospital-based cross-sectional study. Sci World J. 2012:2012:9.

23. Harpham T, Huttly S, Silva MJ, Abramsky T. Maternal mental health and child nutritional status in four developing countries. J Epidemiol Community Heal. 2005;59:1060-4.

24. Ola B, Crabb J, Tayo A, Ware SHG, Dhar A, Krishnadas R. Factors associated with antenatal mental disorder in West Africa : A cross-sectional survey. BMC Pregnancy Childbirth. 2011;11(90).

25. Uriyo JG, Abubakar A, Swai M, Msuya SE, Stray-pedersen B. Prevalence and correlates of common mental disorders among mothers of young children in Kilimanjaro region of Tanzania. PLoS One. 2013;8(7):1-7.

26. Kaaya SF, Wambo MB, Lonzo KI, Borne VD, Shabari LE, Schaalma SF. Socioeconomic and partner relationship factors associated with antenatal depressive morbidity among pregnant women in Dar es Salaam, Tanzania. Tanzan J Health Res. 2010;12(1).

27. Hartley M, Tomlinson M, Greco E, Comulada WS, Stewart J, Roux I, et al. Depressed mood in pregnancy: prevalence and correlates in two Cape Town peri-urban settlements. Reprod Health. 2011;8(1):9.
28. Ayele TA, Azale T, Alemu K, Abdissa Z. Prevalence and associated factors of antenatal depression among women attending antenatal Care Service at Gondar University Hospital. Northwest Ethiopia PLoS One. 2016;1 1(5):1-12.

29. Bisetegn TA, Mihretie G, Muche T. Prevalence and predictors of depression among pregnant women in debretabor town, northwest Ethiopia. PLoS One. 2016;11(9).

30. Biratu A, Haile D. Prevalence of antenatal depression and associated factors among pregnant women in Addis Ababa, Ethiopia : a cross-sectional study. Reprod Health. 2015;12(99):1-8.

31. De Vargas C, Coll N, Freitas M, Garcia D, Netsi E, César F, et al. Antenatal depressive symptoms among pregnant women : evidence from a southern Brazilian population-based cohort study. J Affect Disord. 2017; 209(November 2016):140-6.

32. Nasreen HE, Kabir ZN, Forsell Y, Edhborg M. Prevalence and associated factors of depressive and anxiety symptoms during pregnancy : a population based study in rural Bangladesh. BMC Womens Health. 2011;11(1):22.

33. Karmaliani R, Asad N, Bann CM, Goldenberg RL. Prevalence of anxiety, depression and associated factors among pregnant women of Hyderabad. Pakistan Int J Soc Psychiatry. 2009;55(5):414-24.

34. Faisal-cury A, Menezes PR. Common mental disorders during pregnancy: Prevalence and associated factors among low-income women in São Paulo ... Arch Womens Ment Health. 2009:12(June):335-343.

35. Rungruxsirivorn T, Taechakraichana N. Associated factors of prenatal depression among teenage pregnant women at King Chulalongkorn Memorial Hospital. J Med Assoc Thail. 2015;98(5):437-43.

36. Nagandla K. Prevalence and associated risk factors of depression, anxiety and stress in pregnancy. Int J Reprod Contraception, Obstet Gynecol. 2016; 5(7):2380-8.

37. Fisher J, Tran T, Kriitmaa K, Tran T. Common perinatal mental disorders in northern Viet Nam : community prevalence and health care use. Bull World Heal Organ. 2010;88:737-45.

38. Fisher JRW, Tran T. Relative socioeconomic advantage and mood during advanced pregnancy in women in Vietnam. Int J Ment Health Syst. 2007;1(3):1-9.

39. Peltzer K, Rodriguez VJ, Jones D. Prevalence of prenatal depression and associated factors among HIV-positive women in primary care in Mpumalanga province. South Africa J Soc Asp HIV/AIDS. 2016;13(1):60-7.

\section{Publisher's Note}

Springer Nature remains neutral with regard to jurisdictional claims in published maps and institutional affiliations.

\section{Ready to submit your research? Choose BMC and benefit from:}

- fast, convenient online submission

- thorough peer review by experienced researchers in your field

- rapid publication on acceptance

- support for research data, including large and complex data types

- gold Open Access which fosters wider collaboration and increased citations

- maximum visibility for your research: over $100 \mathrm{M}$ website views per year

At $\mathrm{BMC}$, research is always in progress.

Learn more biomedcentral.com/submissions 